\title{
Keeping Communities Healthy: The Islamic Paradigm
}

Nordin $M M$

\begin{abstract}
$\underline{\text { Abstract }}$
One of the five matters before being overtaken by its opposite as advocated by the Prophet (SAW) was "your health, before you fall sick" (Muslim). This concept of the Prophet's Medicine (Tibb Nabawi) has been much discussed and unfortunately misunderstood, even abused in recent times. This paper attempts to examine the Quranic exhortations on health and healing and its practices as exemplified by authentic traditions of the Prophet (SAW). This would enable us to extract guiding principles about various healthcare issues including holistic care, preventative strategies, training, bioethics, hospital services, clinical research and global health.
\end{abstract}

International Journal of Human and Health Sciences Vol. 02 No. 02 April'18 Page : 49-54

\section{Health: A blessing from Allah}

Health is a precious gift, a blessing from Allah (SWT) which should be protected and enhanced. Without good health, we would not be able to live up to our physical potential as His Khalifah (vicegerent) on earth to undertake amar maaruf nahi mungkar, to enjoin good and to forbid evil and to pursue the communal quest for adlwaihsan(justice with fairness and mercy), the preservation of public interest (maslahah amah), mutual benefit (masalih mushtarakah) and protection from harm (dar' al mafasid).

Unfortunately, this blessing is often forgotten or not prioritized by many amongst us. This was alluded to by the Prophet Muhammad (SAW) when he said;

"There are two blessings which many people do not appreciate, health and leisure time" (Muslim \&Bukhari)

\section{Quranic verses of healing}

And although the Quran is primarily a book of hidayah (guidance), it nonetheless makes reference to health and healing. Six verses in the Quran have been described as verses of shifaa' (healing).

One of these verses, in surah As-Shu'ara, 26:80, describes Prophet Ibrahim's (AS) recognition of his Ultimate Healer;

"And when I fall sick, He heals me"
And to the Jewish community during the time of Prophet Isa (AS), where the healers were held in high esteem, Prophet Isa (AS) was sent with medical miracles (mu'jizat), emphasizing the need to be at the cutting edge of medical sciences:

"... And I cure the blind and the leper, and I give life to the dead - by permission of Allah ..." (AliImran, 3:49)

\section{Health within the context of the} MaqasidShari'ah

The cardinal purposes of the Muslim's individual, community, national and global life experiences have been comprehensively defined by the MaqasidShari'ah, the higher objectives of Islamic jurisprudence ${ }^{1}$. The well being of the community is protected by the preservation of the fiveessentials(daruriyyat) in human life, namely faith and morality (deen), life (nafs), intellect ('aql), progeny (nasl) and wealth (maal).

Allah says in Surah Al-Maidah, 5:32;

"And if anyone saved one life, it would be as if he had saved mankind entirely"

Three of the priorities of the MaqasidShari'ah are directly related to health whilst the first (deen) and the fifth (maal) essentials in the hierarchy, though indirect are intimately associated. Thus, the objectives of the healthcare system are to nurture a community which is healthy and morally upright, prevent premature and inappropriate

Correspondence to: Dato' Dr Musa Mohd Nordin FRCP (Edin), FRCPCH (UK), FAMM Chairman, Advisory Board Federation of Islamic Medical Associations (FIMA) 
deaths, protect against intellectual and physical disabilities, promote safe reproduction and proliferation of the human seed through the utilization of health intervention programs which are cost-effective.

\section{A bias for preventative health strategies}

A pervasive thread in the Islamic paradigm, whether in economic, social or health matters is the emphasis on preventative strategies. The prevention of diseases and the preservation of wellness are pillars of best practices in medicine. Apart from the injunctions in the Quran and authentic hadiths, it is based on a principle of jurisprudence, غعيرذذادس, closing all avenues of destruction.

Several principles of health care practises and interventions can be summarized as follows ${ }^{2}$ :

- The Prophet Muhammad (SAW) said, "Cleanliness is half of faith (iman) (Muslim)". This hadith which connects cleanliness with belief is a cornerstone in Islam's advocacy for optimal health.

- The Quran advocates healthy eating and encourages the believers to eat only permissible and good food

"O mankind, eat from whatever is on earth [that is] lawful and good and do not follow the footsteps of Satan. Indeed, he is to you a clear enemy." (AlBaqarah 2:168).

There are numerous statements that have been recorded in both the Qur'an and the hadith of the Prophet (SAW) encouraging Muslims to be moderate in eating and drinking.

And eat and drink and be not extravagant; surely He does not love the extravagant. (Al-A 'raf 7: 31)

"No human ever filled a container more evil than his belly. The few morsels needed to support his being shall suffice the son of Adam. But if there is no recourse then one third for his food, one third for his drink and one third for his breath." (Ahmad and At-Tirmidhi)

- The prophet (SAW) in various hadiths enjoined his companions to exercise. He said, "A strong believer is better than a weak believer" (Muslim). Thus, a Muslim is enjoined to be not only strong in faith and character but also in physical strength and fitness through regular exercises.

- Islam recognises the existence of contagious diseases and the Prophet (SAW) commanded us to avoid such diseases. He said: "Run away from the leper same as you would from a lion." [Bukhari and Muslim].

- Islam also introduced the concept of quarantine in the event of an infectious outbreak. The Prophet (peace be upon him) said: "If you hear that a land has been stricken by plague, do not approach it, and if your land is stricken by plague, do not leave it". [Sahîh al-Bukhari]

\section{Health professional training versus quackery}

The believers are urged to seek medical treatment when they are ill. And when a cure is available some scholars would even suggest it as being mandatory. The Prophet (SAW) said:

"Seek medical treatment, for truly Allah does not send down a disease without sending down a cure for it. Those who have knowledge of the cure know it, and those who are ignorant of it do not." [Musnad Ahmad]

The Prophet (SAW) is also reported to have said:

"He is not one of us who is not kind to children or does not respect our elders, or denies our learned people the esteem they deserve" (Abu Dawud, AlTirmidhi)

The two earlier hadiths also illustrates Islam's high regard for people who are experts and highly trained in their specialty and Muslims are enjoined to seek treatment from these health professionals. This hadith is especially instructive and relevant in this modern world of information and communication technology where individuals and groups claim to be overnight experts in medicine by simply accessing information from the internet. An incident which happened during the time of the Prophet Muhammad (SAW), further emphasizes the importance of authentic knowledge and specialty training. When a man fell ill, the Prophet (SAW) said,

"Summon the physician of the tribe so and so for him." (Ahmad).

It also shows the Prophet's (SAW) criticism of the ignorant who blindly practise the art of healing without the pre-requisite medical knowledge and skills.

\section{Code of medical ethics}

The early physicians who worked in the medieval Muslim hospitals were required to follow a strict code of ethical practices. Ishaq bin Ali al-Rahawi's (854-931 AD) Adab al-Tabib (The conduct of a physician), is the earliest known Arabic treatise dedicated to medical ethics. Rahawi considered physicians as "guardians of souls and bodies" and in this treatise he spells out all the deeds and acts a Muslim physician must observe.

$\mathrm{He}$ also described the process of licensing physicians, when he wrote: “...the physician was not allowed to sit for treating patients until after 
he passes the generally aforementioned tests and examinations..."

This was later enforced into law during the Abbasid Caliphate whereby all doctors were required to pass an examination before being allowed to practice medicine. This physician licensure became mandatory after the Caliph Al-Muqtadir, in $931 \mathrm{AD}$, was informed of the death of one of his subjects due to a physician's error.

\section{Individual autonomy versus community interest}

The ethical principle of autonomy highly respects and values the individual (or parents or legal guardians) as the one who makes the self-defining choices upon which he then acts and for which he is accountable.

This however needs to be considered within the context of the wider public interest and benefits (maslahah ammah). This is defined by the Islamic legal maxim (al-Qawa'id al-Fiqhiyyah) which stipulates: "individual rights may have to be sacrificed in order to protect the public interest." In the domain of healthcare, medical interventions such as global immunization programs, which have been proven to promote and protect the general health and well being of the community, have priority over the considerations of the individual interest.

\section{The early Muslim hospitals}

The Prophet's mosque in the city of Madinah held the first Muslim hospital service in its courtyard. During the GhazwahKhandaq (battle of the trench), Muhammad ordered a tent to be assembled to provide medical care to the wounded soldiers. Among those who attended to the injured soldiers was the first Muslim nurse, Rufaida al-Aslamia. The prophet Muhammad (SAW) used to order all casualties to be carried to her tent so that she might treat them with her nursing and medical expertise. This later evolved into the many bimaristans, a Persian word meaning "house of the sick", during the early Islamic rule. The Umayyad Caliph AlWalidibnAbd al-Malik is often credited with building the first bimaristan, in Damascus in 707 AD.

Many of these early hospitals were built with charitable endowments, waqf $f^{3}$. They were staffed by salaried physicians who did regular ward rounds. Pharmacists dispensed medicines from the well equipped dispensaries. There were separate wards for men and women and wards were segregated according to the type of illnesses. Patients were nursed until they have fully recovered and upon discharge were given a sum of money for their immediate personal needs. There is good reason to believe that the Christians were impressed by the hospitals they overran during the crusades. A network of hospitals later spread across Europe which were influenced and modeled on the famous Islamic hospitals in Cairo and Damascus.

\section{Search for cures and the first clinical trials}

Abu Hurairah (RA) narrated that the Prophet (SAW) said:

"There is no disease that Allah has created, except that He also has created its remedy." (Bukhari)

In this and several other hadiths, the Prophet (SAW) advocated research into the finding of cures for ailments, thus urging the believers to be at the frontiers of medical research.

This inspired the likes of physician, Al-Razi (854 - $925 \mathrm{AD})$ who carried out the earliest known example of a clinical research trial on the effectiveness of bloodletting in the treatment of patients with meningitis by employing a control group. This demonstrates Al-Razi's commitment to evidence based medical science ${ }^{4}$.

IbnSina (980 - $1037 \mathrm{AD})$ in his magnum opus, $\mathrm{Al}$ Qanun Fi Tibb (The Canons of Medicine) outlined 7 principles before a medicine can be considered to be effective ${ }^{5}$. Among others he emphasized that trials which were successful in animal models must be replicated in human subjects. And that the results of the trials should be reproducible in other similar research.

In this respect, the Wakefield claim of the link between the MMR vaccine and autism has never been reproduced in other studies. On the contrary, this claim has been debunked in at least 67 different studies. ${ }^{6}$

\section{Health status in Muslim countries}

There are over 1.8 billion Muslims living in 57 Muslim majority countries. The health of the Muslims communities can be benchmarked against a set of 8 Millennium Development Goals (MDG), from the baseline statistics in 1990 up to 2015.?

MDG 4, 5 and 6 are directly related to the health of the communities whilst the health sector is an important stakeholder in the other five MDGs.

MDG 4 calls for a $2 / 3$ reduction in the mortality of children under 5 years old by 2015. 1 in 12 children die in Muslim countries compared to 1 in 18 in world. Many of these under five deaths are preventable with the introduction of basic public health interventions which include, access to safe 
drinking water, good nutrition, breastfeeding, hygienic sanitation and immunization. ${ }^{8}$

MDG 1 calls for the eradication of extreme poverty and hunger and among others targets to halve the proportion of people who suffer from hunger. Nearly half of the under- 5 children in some Muslim countries are underweight and stunted. And one of the major risk factor for under-5 deaths is malnutrition. Thus the close relationship between the economic status of communities, rates of malnutrition of its mothers and children and a health indicator as in MDG 4.

MDG 5 calls for improvement of maternal health, through $3 / 4$ reduction of maternal deaths. Many Muslim countries are not on track to achieve MDG 5. In Afghanistan 1 in 6 pregnancies results in death, in Africa 1 in 15 as against the global average of 1 in 74 pregnancies. This is due to the high fertility rates, low average age of pregnancies, illiteracy, lack of antenatal care, lack of access to skilled obstetric care and complicated by the compromised social and economic status of women in these communities.

Some Muslim countries have however made considerable progress in their health programs. Maldives and Iran have reduced their maternal mortality ratios by more than $80 \%$ and are on target for MDG 5.

The under-5 mortality in Malaysia has been significantly reduced from 16.8 to 7.7 per 1,000 live births from 1990 to 2012 . The maternal mortality ratio declined from 44 to 25.6 per 100,000 live births from 1991 to 2012. The challenges for Malaysia to be on track for MDG 4 and 5 is to enhance health care providers' knowledge and skills, provision of family planning services for high risk mothers, expansion of the Integrated Management for Childhood Illness Program and prevention of childhood injuries. ${ }^{9}$

Progress in the health status of other Muslim communities have been hampered by natural disasters, economic crises, political instability, armed conflicts, rural urban migration, breakdown of basic social structures and ultra-conservatism of some of its religious scholars.

\section{Reclaiming the lost heritage and moving forward}

History will testify that the early Muslim scientists dominated virtually most aspects of knowledge and research from $600-1700$ AD. Az-Zahrawi (930-1013 AD), the father of modern surgery, was pioneering new surgical instrumentations when Europe was restricted by a religious edict in 1163
AD which ruled:

"All forms of surgery must be stopped in all medical school by all surgeons"

Is it any wonder that Martin Kramer, an American historian wrote ${ }^{10}$ :

"Had there been Nobel Prizes in 1000, they would have gone almost exclusively to Muslims."

Somehow, Muslim communities have lost it along the way and have lagged behind in developing their health systems which they once led and inspired the world during the glorious days of Islamic civilization.

Religious conservatism, has undoubtedly been one of the contributory factors to the decline and stagnation of the pursuit of science and the spirit of enquiry and research in the Muslim world today. In the eradication of smallpox, the last few cases were from Bangladesh and Somalia. And the Global Polio Eradication Initiative (GPEI) targets 2018 to end polio and three Muslim countries are still polio endemic, namely, Afghanistan, Nigeria and Pakistan. ${ }^{11}$

We should never loose sight of the compassionate and humane nature of Islam as exemplified in surah al-Hajj, 22:78:

"And strive for Allah with the striving due to Him. He has chosen you and has not placed upon you in the religion any difficulty."

And an authentic tradition further fortified this concept as narrated by Aisha (RA)

"If given an option between 2 actions, the Prophet (SAW) would surely choose the easier one, as long as it is not sinful." (Bukhari)

When deliberating the permissibility of the Oral Polio Vaccine (OPV) which is manufactured using porcine-based trypsin, at the 11th Session of the European Council of Fatwa \& Research (ECFR) from 1-7 July 2003, in Stockholm, the ECFR concluded $;{ }^{12}$

"The Council urges Muslim leaders and officials at Islamic Centers not to be too strict in such matters that are open to considered opinion and that bring considerable benefits to Muslim children, as long as these matters involve no conflict with any definite text."

And we firmly believe this spirit and approach pervades the corpus of the jurisprudence of facilitation (Fiqh Taysir). At no point in time does it blemish the belief nor practice of the faithful because scholars have anticipated the challenges of modernity and have reiterated;

"Allah will bless the believer who recognises and engages with the new world, yet remains true to 
his religious values."

Investments in the health and education of Muslim communities should be among the major priorities of our political and economic leaders. The caliphs of the early Islamic era took a very keen interest in the building of health infrastructure. In the early tenth century, Caliph al-Muktafi (died 907), called upon al-Razi to decide on the selection of a site for the new hospital. Al-Razi hung up pieces of meat in various districts of Baghdad and advised the site where the meat decayed the least to be selected. This is the first scientific observation of unknown particles (germs) in air which led to air borne diseases!

Caliph al-Muqtadir (ruled from 908-932 AD), his successor, built several more hospitals and staffed them with the best physicians, many of them Christians and Jews; and filled the libraries with the latest books and writings. Hospitals were also found in the other large cities in the Islamic empire, notably Cairo and Cordoba, whilst Europe was still trapped in the "Dark Ages".

We hope and pray to Allah (SWT) that our Muslim communities would be governed by similarly enlightened political and socio-economic leadership. In this context, it is worthwhile considering the wise words of Pervez Hoodbhoy, a Pakistani physicist, who wrote; ${ }^{13}$

"With well over a billion Muslims and extensive material resources, why is the Islamic world disengaged from science and the process of creating new knowledge? Common sense and the principles of logic and reason (are) our only reasonable choice for governance and progress. Being scientists, we understand this easily. The task is to persuade those who do not."

We also hope and pray to Allah (SWT) that our countries would be similarly blessed with peace, security and protected from major natural disasters. And that as a community we would be inspired by the following hadith, to catch up on lost ground and rejuvenate our quest for leadership in the medical sciences and other aspects of scientific scholarship in the continuous process of islah(transformation) towards the community's health and well-being. "A word of wisdom is the lost property of a Muslim. He should seize it wherever he finds it." (At-Tirmidhi) 


\section{References}

1. Shari'ah Intelligence. The basic principles and objectives of Islamic jurisprudence. Islamic Education Trust Nigeria. August 2015: 161

2. Musa MN et al. Immunisation controversies. What you really need to know. August 2015:90-93

3. PE Pormann et al. Medieval Islamic Medicine.. American University in Cairo Press, 2007. Page 9

4. Jim Al-Khalili.The golden age of Arabic science. 2012:138-51

5. Abdul Rashid AR. Medicines, supplements and herbs for women. Fiqh Medicine Convention 2.0. 19 April 2015

6. Margaret A. Maglione et al. Safety of Vaccines Used for Routine Immunization of US Children: A Systematic Review. Pediatrics. June 2014

7. http://www.un.org/millenniumgoals/ accessed 13
Dec 2015

8. Health in the Muslim world: Meeting the MDGs. FIMA Year Book 2012. Pages 13-18

9. http://www.moh.gov.my/images/gallery/ publications/HEALTH\%20FACTS\%202014.pdf accessed 13 Dec 2015

10. Martin Kramer.Islam's Sober Millennium. Jerusalem Post. December 31, 1999.

11. GPEI Scientific Declaration on Polio Eradication 2013. Immunisation Controversies-What you really need to know. August 2015: 208-209

12. Fatwa 11/11. The 11th regular Session of the European Council of Fatwa \& Research. 1-7 July 2003. Stockholm, Sweden.

13. Pervez AmiraliHoodbhoy.Science and the Islamic world-The quest for rapprochement. Physics Today; 2007;49:49-55 